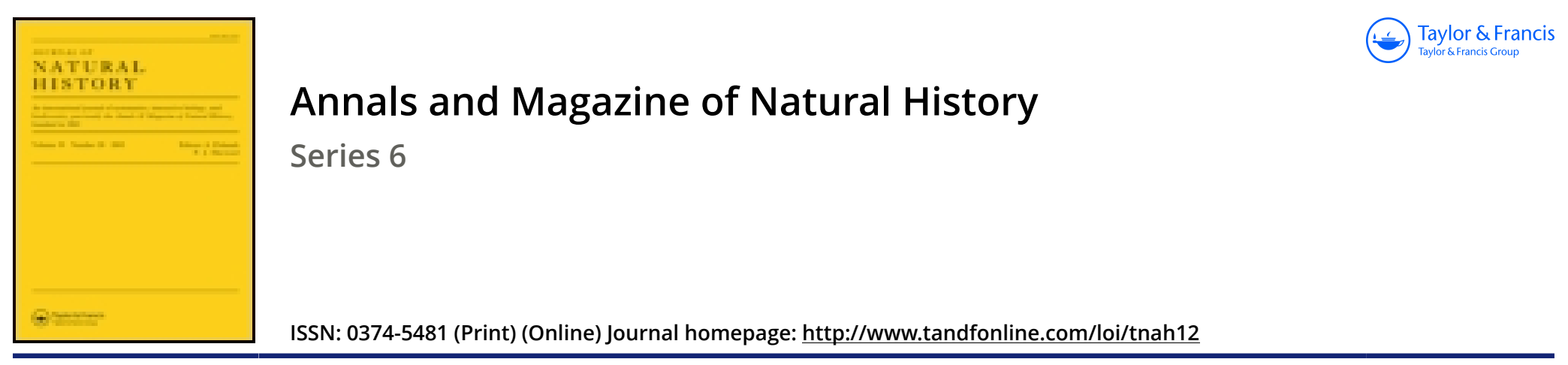

\title{
XLIV.-Description of a new moth of the genus Anaphe from Madagascar, with a note on the natural position of the genus
}

\section{Arthur G. Butler F.L.S. F.Z.S.}

To cite this article: Arthur G. Butler F.L.S. F.Z.S. (1892) XLIV.-Description of a new moth of the genus Anaphe from Madagascar, with a note on the natural position of the genus, Annals and Magazine of Natural History, 10:59, 398-399, DOI: 10.1080/00222939208677431

To link to this article: http://dx.doi.org/10.1080/00222939208677431

曲 Published online: 02 Oct 2009.

Submit your article to this journal $₫$

Џ Article views: 3

Q View related articles $₫$ 
XLIV.-Description of a new Moth of the Genus Anaphe from Madagascar, with a Note on the Natural Position of the Genus. By ArThur G. BuTler, F.L.S., F.Z.S., \&c.

THE following new species, together with its long fusiform social cocoon (not unlike that of Hypsoides bipars), was obtained by the Rev. J. Wills in the forest of East Imerina :-

\section{Anaphe aurea, sp. n.}

Wings above uniform pale silky golden buff, the males with the basal half of the costal margin slenderly edged with black; below, the borders of the wings are more ochraceous than above. Body above testaceous, with the head and collar more or less deeply orange; antennæ and eyes black: body below deep ochreous, the inferior edge of the palpi, a few hairs at the front of the pectus, and the tarsi of all the legs black; the tibiæ of the anterior and middle pair black, fringed with ochreous, those of the posterior pair blackish at their distal extremity; anal tuft of female silvery above, otherwise coffee-brown.

Expanse of wings, of 51, o 62 millim.

Forest of East Imerina, Madagascar.

Four males and two females were sent with the cocoon.

The position of the genera Anaphe and Hypsoides has long been debated by Lepidopterists. Thus Walker (Lep. Het. iv. p. 856) described Anaphe as a genus of the family Liparidæ, whilst Herrich-Schäffer in the same year referred it to the Notodontidæ under the generic name Arctiomorpha; whereas Dr. Boisduval (Voy. de Delegorgue, 1847) seems to have imagined that it was an Arctiid. In his article on Anaphe (Trans. Linn. Soc. 1885) Lord Walsingham speaks of some of its characteristics as shared by Cnethocampa, and M. Mabille, speaking of his genus Conostegia (a synonym of Hypsoides), says that it belongs to a special division of Bombyx approaching nearly to the European Cnethocampa (Bull. Soc. Ent. France, 1890 (published 1891), p. cxlvi).

Mr. G. F. Hampson, who has recently made a careful study of the families of the Lepidoptera, has pointed out to me that under the so-called Lasiocampida of authors two very distinct families are confounded, one of which (the true Lasiocampidæ) has the lower radial vein of the anterior wings emitted from the posterior angle of the cell; the other (Eupterotida, Hampson) emits this vein from the centre of 
the discocellular veinlet. The Eupterotidæ moreover can at once be distinguished from the Lasiocampida by the important character of their well-developed frenulum, this being entirely absent in the Lasiocampidæ. The larvæ of the Lasiocampidæ are densely hairy, often with long thick tufts directed forwards on either side of the head, or backwards from the anal segment, as in the Liparidæ (to which Mr. Hampson considers them allied) ; whereas the larvæ of the Eupterotidæ are more Arctiid in character, such hairs as there are, whether few or many, being chiefly emitted in tufts from wart-like excrescences.

There can be no doubt whatever, from the entire structure of the moths and the character of their larvæ, that Anaphe and Hypsoides must be placed in the family Eupterotidæ of Hampson.

\section{XLV.-The Interpretation of the Sponge Organism, and some Recent Worles on Sponges. By Dr. OTTo MaAs*.}

Since the investigations of F. E. Schulze on the structure and development of sponges paved the way, probably all zoologists have looked upon these animals as three-layered, consisting of an outer and an inner layer of epithelium, and enclosed by these a connective-tissue mass with cells and deposits of various kinds. This method of interpretation does not take into consideration the question whether the three layers correspond to the layers which arise from ectoderm, endoderm, and mesoderm in higher animals, and also does not necessitate our holding any particular view regarding the systematic position of sponges. As a matter of fact the adherents of the most divergent theories on this pointboth those who derive sponges from a special class of Protozoa separated from other Metazoa, and those who consider them as true Metazoa, but as a special phylum, as well as, finally, those by whom sponges are regarded only as a degenerate branch of the Coelenterate stem-have all recognized the three-layered structure of sponges in their speculations.

A nother question specially referring to the group of sponges would be whether the three layers of the adult arise in the development of the individual sponge from three separate

* Translated from a separate impression, communicated by the Author, from the 'Biologisches Centralblatt,' Bd. xii. nos. 18-19, pp. 566-572 (Uct. 1892). 